\title{
Bacterial Contamination at Huntington Beach, California- Is It From a Local Offshore Wastewater Outfall?
}

During the summers of 1999 and
2000, beaches at Huntington Beach,
California, were repeatedly closed
to swimming because of high bacte-
ria levels in the surf zone. The city's
beaches are a major recreational and
commercial resource, normally attract-
ing millions of visitors each summer.
One possible source of the bacterial
contamination was the Orange County
Sanitation District's sewage outfall,
which discharges treated wastewater
4.5 miles offshore at a depth of 200
feet. Scientists from the U.S. Geologi-
cal Survey and cooperating organiza-
tions have been investigating whether
ocean currents and waves transport
the wastewater to the beaches. These
studies indicate that bacteria from the
outfall are not a significant source of
the beach contamination.

The wide sandy beaches at Huntington Beach, California, just south of Los Angeles, attract residents and visitors alike. Typically, more than 5 million people visit these beaches each summer, helping to support a regional tourism industry of $\$ 80$ million annually.

During the summers of 1999 and 2000 , stretches of these beaches had to be repeatedly closed to swimming or posted with advisories against swimming, because levels of live bacteria in the surf zone exceeded beach sanitation standards in the California Health and Safety Code (Assembly Bill 411, or AB411). Because people stayed away from the beaches, local recreational and beachfront business communities suffered serious economic losses.

Local agencies conducted a variety of studies in 1999 and 2000 to try to

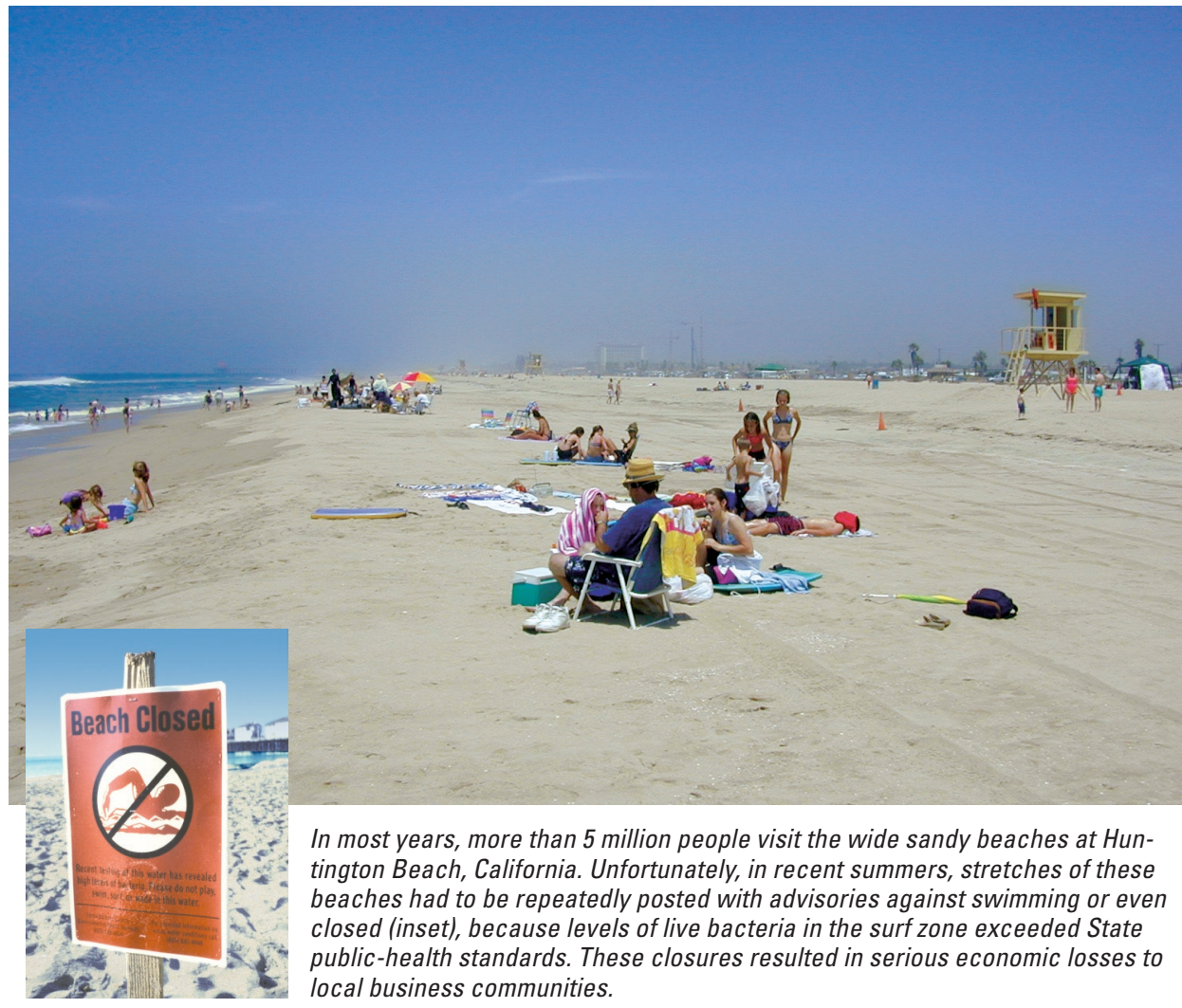

determine the cause of the beach contamination at Huntington Beach. They investigated known sources of bacteria, such as broken sewer pipes, outflow from the Santa Ana River, feces of bird populations in coastal marshes, and the plume of treated wastewater from the Orange County Sanitation District's (OCSD) ocean outfall, 4.5 miles $(7 \mathrm{~km})$ offshore at a depth of 200 feet $(60 \mathrm{~m})$. The beach closures were caused by elevated levels of three categories of bacteria-total coliform, fecal coliform, and enterococci. These bacteria, which live in the digestive tracts of warm-blooded animals including humans, are also found in the treated effluent discharged from the OCSD outfall. Because of this, it was suspected that coastal ocean processes might be bringing bacteria-rich effluent from the ocean outfall to shore.
To evaluate whether the OCSD outfall could be the source for the bacterial contamination at Huntington Beach, scientists from the U.S. Geological Survey (USGS) and cooperating organizations

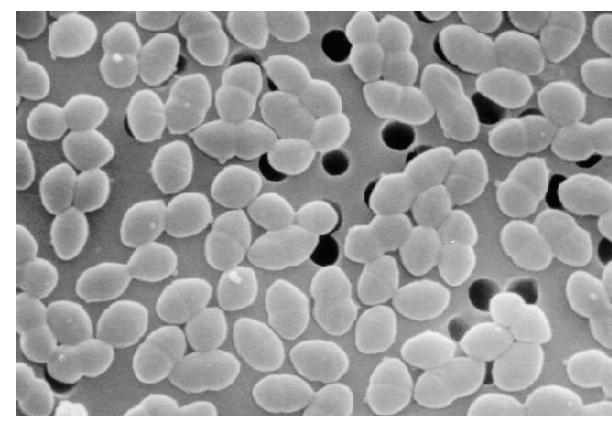

This photo shows many enterococci bacteria (magnified more than 5,000 times), one type of bacteria indicative of contamination from feces of humans or other warm-blooded animals. High levels of enterococci have been responsible for many of the beach closures at Huntington Beach. (Photo courtesy Centers for Disease Control and Prevention.) 
designed and carried out an extensive study. Begun in the summer of 2001, this study focused on the area's coastal ocean circulation and transport pathways.

It was known from the 1999-2000 studies done by local agencies that the beaches were most often contaminated during "spring" tides in the 2-week tidal cycle. Spring tides occur when the gravitational pulls of the Moon and Sun reinforce each other, resulting in the highest high waters and lowest low waters of this cycle. Additionally, previous field observations and theoretical modeling indicated that, in summer, the effluent plume from the OCSD outfall remains trapped below the thermocline, a zone of rapid change in temperature that divides ocean water into cold dense water below and warmer, less dense water above. In the ocean off southern California, the thermocline is typically about 50 to 65 feet ( 15 to $20 \mathrm{~m}$ ) below the sea surface during the summer.

In light of these earlier findings, the USGS-led study focused on coastal ocean processes, such as tides, daily sea breezes, upwelling, and vertical mixing, that could move significant volumes of bacteria-laden OCSD plume water from offshore below the thermocline into the nearshore region and surf zone during summer months. In the summer of 2001, scientists deployed a sophisticated set of oceanographic instruments at 12 mooring sites in the coastal ocean off Huntington Beach and Newport Beach to monitor current velocity, temperature, and salinity at selected depths in the water column every few minutes for 4 months. Other instruments at these sites collected real-time meteorological data at the sea surface. Additional instruments were deployed in very shallow water to monitor the transport pathways between nearshore waters and the surf zone. Surf-zone water samples were collected 5 days a week in the early morning hours to measure bacterial levels from Huntington Beach to Newport Beach.

A complementary hydrographic mapping program used arrays of instruments towed or lowered from boats along 10 tow lines and at 40 sites between these lines and the shore during six surveys centered around periods of maximum tidal range (spring tides). The surveys measured the spatial distribution of temperature, salinity, ammonia content, bacteria concentrations, and other properties of the water column. These properties were chosen in part because they could be used to identify and track the relatively low-salinity and ammonia-rich effluent from the OCSD plume. During these surveys, additional surf-zone samples were collected every hour at 11 sites along local beaches to provide additional data to evaluate the spatial and temporal distribution patterns of bacteria from offshore to the surf zone.

Analysis of the data collected in 2001 show that the bacterial beach contamination at Huntington Beach is closely associated with both tidal cycles and time of day. High values of all three categories of fecal indicator bacteria were found preferentially at times of spring tides. Additionally, values were high mainly at night, particularly for enterococci. The data show that bacteria levels in the surf zone decreased to very low levels during sunlit hours, even when beaches were closed or posted for several days. However, previous studies have shown that the categories of bacteria found in the OCSD outfall plume can survive for several days in the deeper, colder water below the thermocline, where they are sheltered from ultraviolet light.

When it enters the ocean, the treated wastewater from the OCSD outfall rises toward the thermocline, because it is fresher, warmer, and therefore less dense than the surrounding ocean water. The
In the summer of 2001, scientists from the U.S. Geological Survey (USGS) and cooperating organizations designed and carried out an extensive study to evaluate whether the Orange County Sanitation District's (OCSD) ocean outfall could be the source of bacterial contamination at Huntington Beach. This study focused on coastal ocean processes that could move significant volumes of bacteria-laden OCSD wastewater into the nearshore region and surf zone during summer months. This map shows locations of instrument-mooring sites, hydrographic survey lines, and surf-zone bacteria sampling stations used in the USGS-led study. At mooring sites, arrays of instruments, such as the tripod shown below being lowered to the sea floor, monitored current velocity, temperature, salinity, and meteorological conditions. Hydrographic surveys used arrays of instruments towed or lowered from boats to measure the spatial distribution of temperature, salinity, ammonia content, bacteria concentrations, and other properties of the water column.

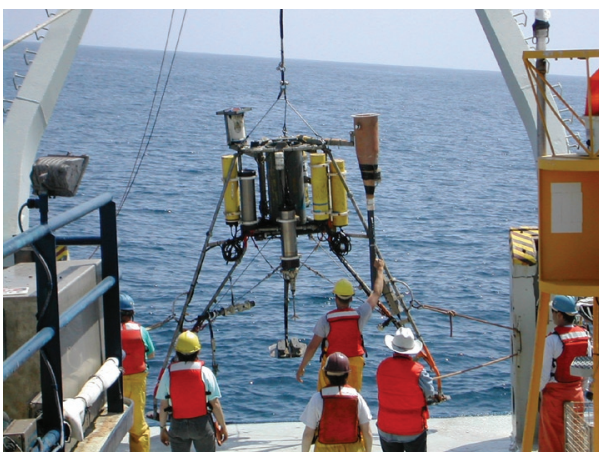

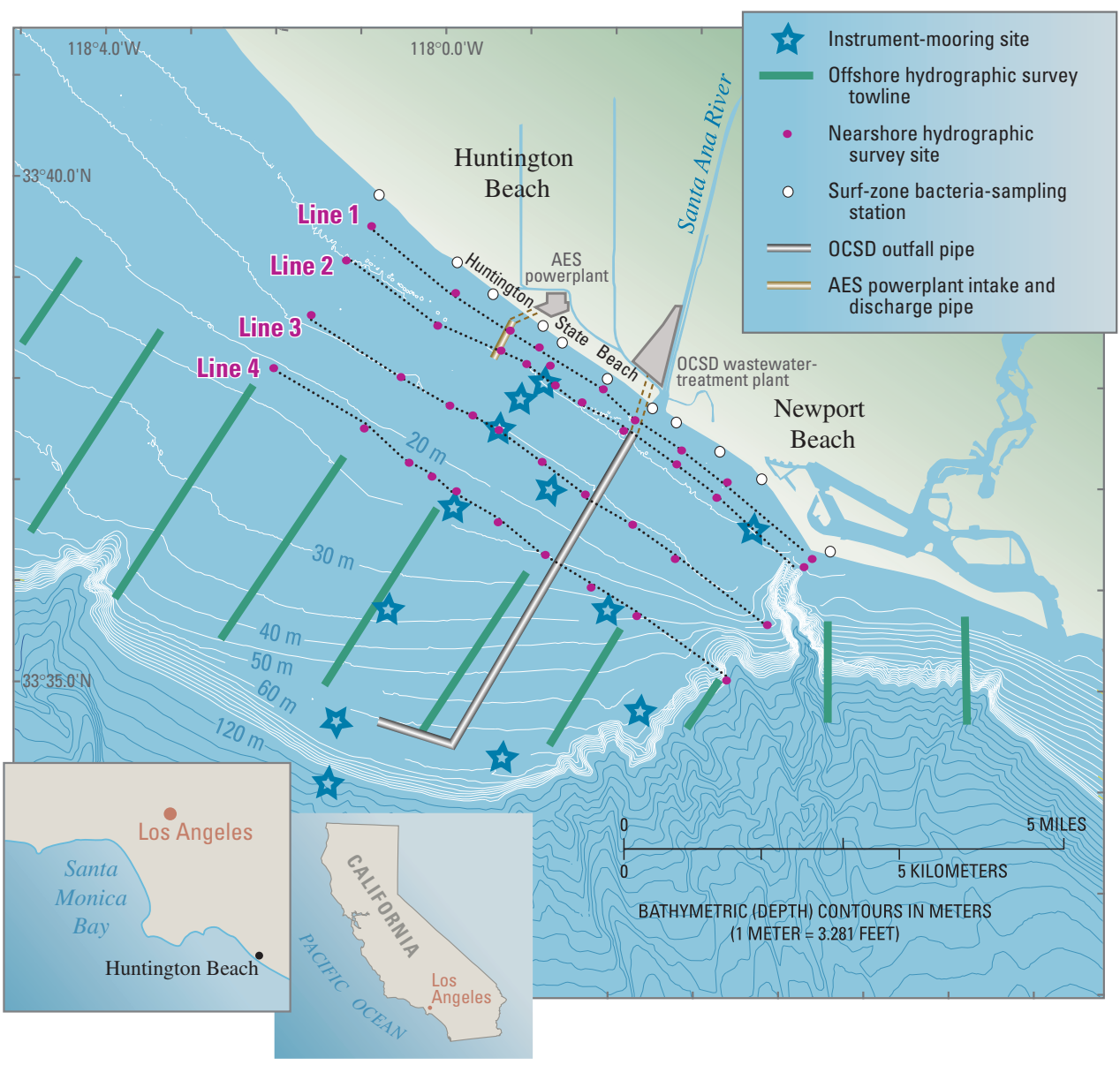


wastewater plume tends to stabilize and mix with a layer of water that has a temperature of 54 to $57^{\circ} \mathrm{F}$ ( 12 to $14^{\circ} \mathrm{C}$ ) and for the most part is carried out of the area by alongshore currents. However, data show that water of that temperature was intermittently brought nearshore during July and August 2001. These cold-water pulses were the result of a combination of internal tides (tidal-cycle waves on density boundaries within the water column, like the thermocline) and daily circulation induced by sea breezes. It had been hypothesized that these mechanisms could bring wastewater from the OCSD plume into the proximity of the cooling-water intake and discharge pipes of the Huntington Beach AES Corporation electrical powerplant, where plume water could be sucked up and then be injected by the discharge jet into surface waters. The OCSD effluent could then easily move into the surf zone through buoyant spreading, wind forcing, or other processes. However, the USGS-led study found no association between the timing of nearshore cold-water pulses and beach closures or postings on the shoreline adjacent to the AES facility, which has been a hotspot for bacterial contamination.
TEMPERATURE PROFILES SHOW NEARSHORE COLD-WATER PULSES

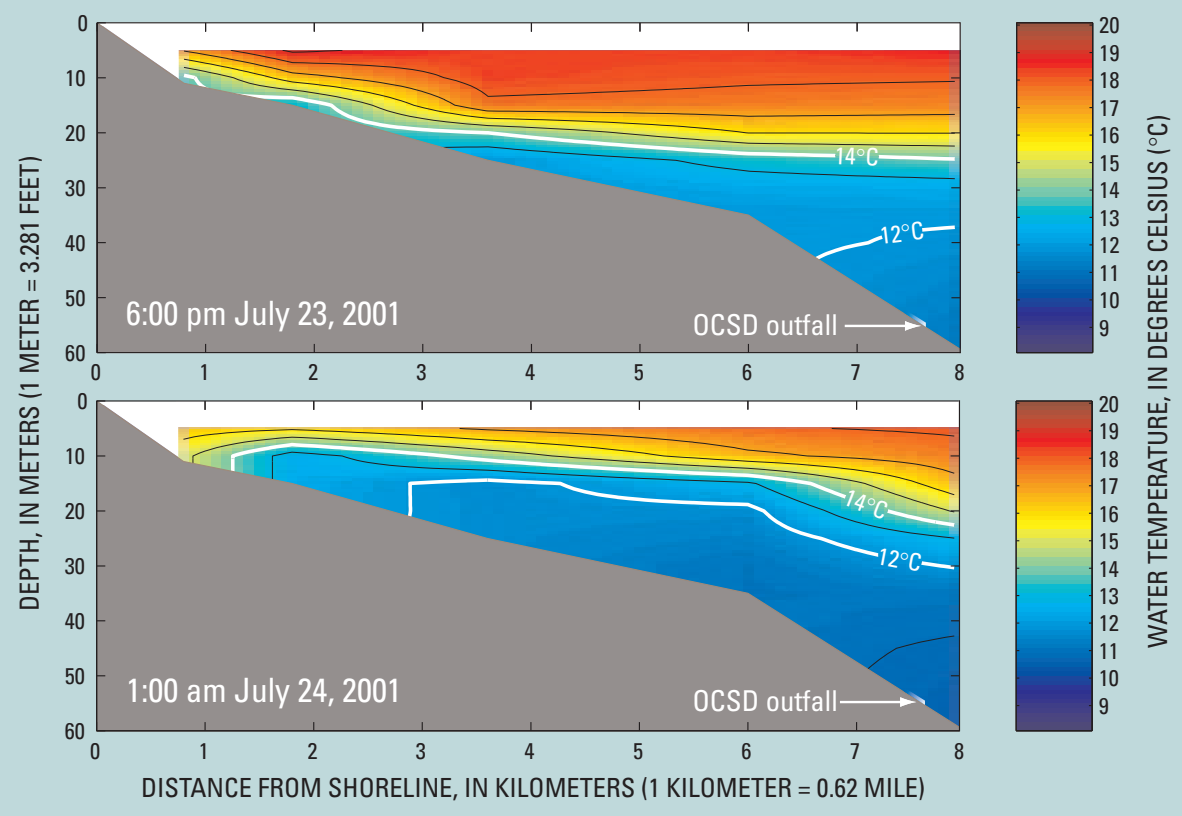

These diagrams show water temperatures offshore of Huntington Beach on the evening of July 23-24, 2001. The upper diagram shows normal summer conditions, in which the thermocline (a zone of rapid change in temperature that divides ocean water into cold dense water below and warmer, less dense water above) is at a depth of about 15 to 20 meters (50 to 65 feet). The lower diagram shows conditions 7 hours later, when a pulse of cold water is moving nearshore below the thermocline. When the treated wastewater plume from the Orange County Sanitation District's (OCSD) offshore outfall enters the ocean, it rises toward the thermocline and tends to stabilize and mix with a layer of water that has a temperature of 12 to $14^{\circ} \mathrm{C}\left(54\right.$ to $\left.57^{\circ} \mathrm{F}\right)$. Water of that temperature was intermittently brought nearshore during July and August 2001, as shown by this example. However, U.S. Geological Survey and cooperating scientists found no association between the timing of these nearshore cold-water pulses and beach closures or postings on the shoreline caused by bacterial contamination.

\section{SALINITY PROFILES REVEAL BODIES OF RELATIVELY FRESHER WATER}

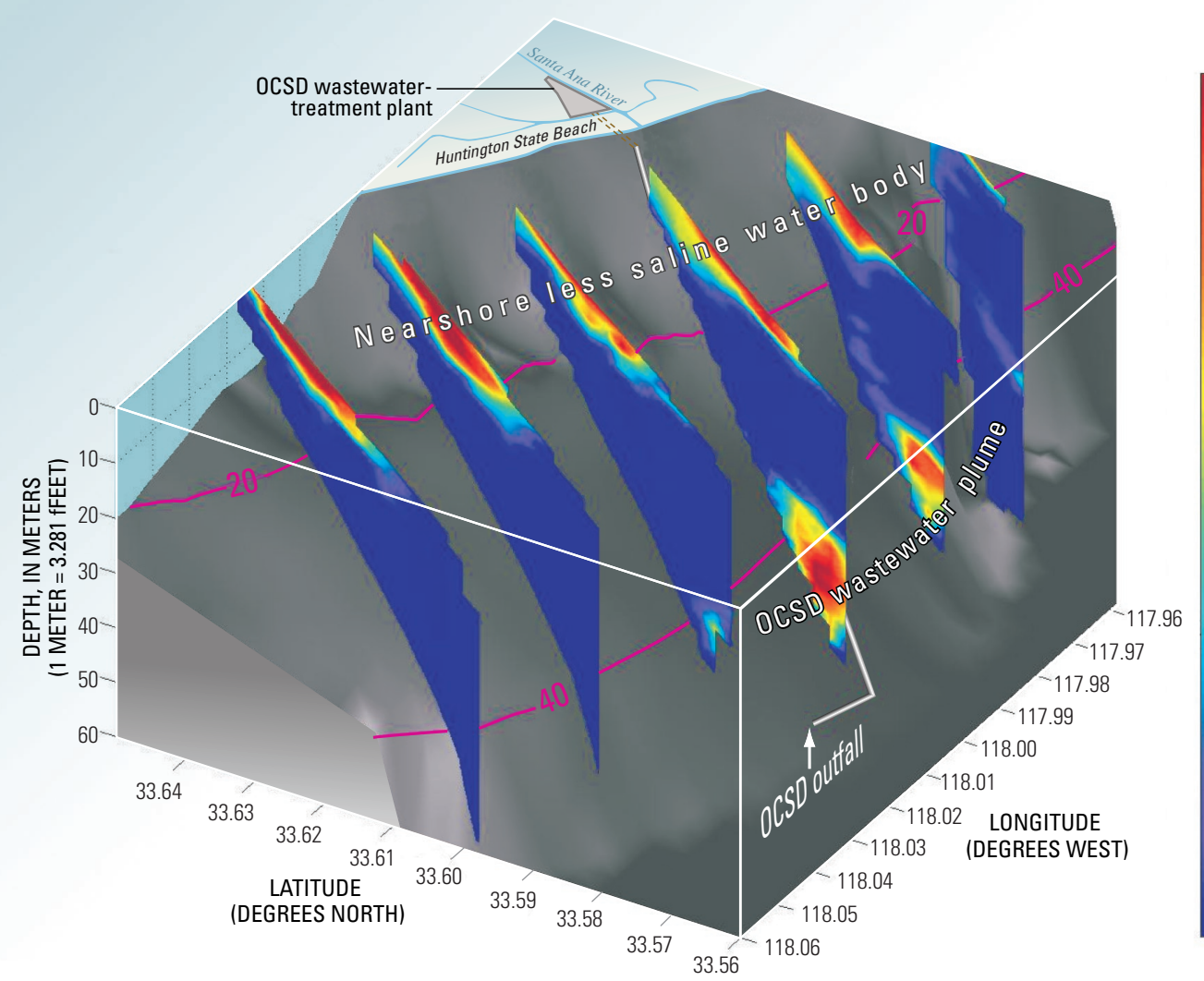

This diagram shows salinity variations offshore of Huntington Beach in early July 2001, measured along hydrographic survey lines (see map). As shown in this diagram, salinity data from the summer of 2001 clearly show two distinct bodies of relatively less saline water-one in deeper water offshore associated with the Orange County Sanitation District's (OCSD) wastewater outfall plume and one in shallower nearshore waters. The nearshore less saline water could be a possible source of the bacterial contamination that has caused beach closures at Huntington Beach. This water may be coming from the San Gabriel and Los Angeles Rivers, to the north, which carry urban runoff into the ocean. 
BACTERIA CONCENTRATIONS REVEAL GAP BETWEEN NEARSHORE AND OFFSHORE CONTAMINATION

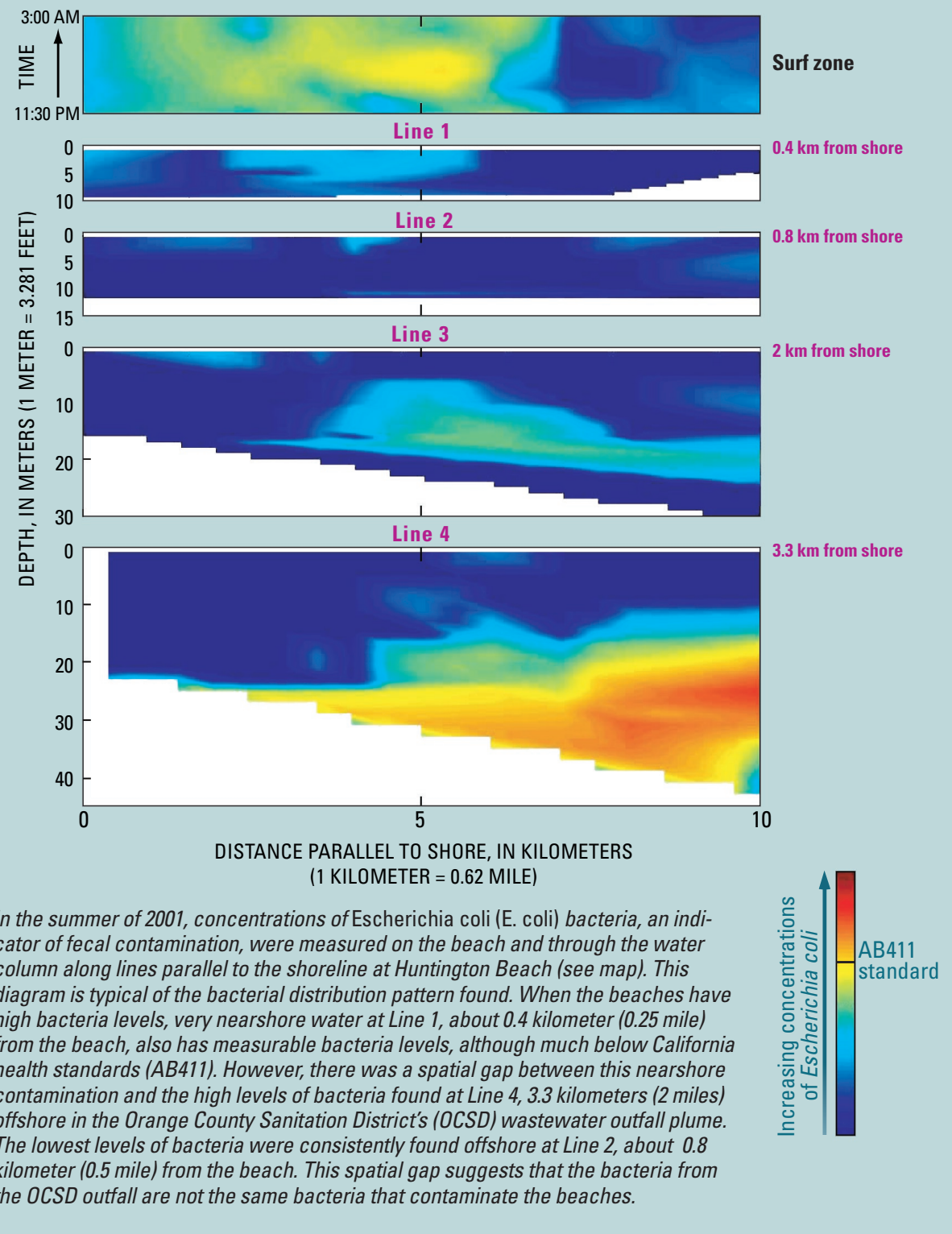

Observations from the USGS-led study provide no evidence that the bacteria found in the OCSD treated-effluent plume reached any part of the shoreline at Huntington Beach in significant enough quantities to cause beach closures or postings. The data show that when the beaches have high bacteria levels, very nearshore water about 0.25 mile $(0.4 \mathrm{~km})$ from the beach also has measurable bacteria levels, although much below AB411 standards. However, there was a spatial gap between this nearshore contamination and the high levels of bacteria measured 2 miles ( 3.3 $\mathrm{km}$ ) offshore below the thermocline in the OCSD outfall plume. The lowest levels of bacteria were consistently found offshore about 0.5 mile $(0.8 \mathrm{~km})$ from the beach. This spatial gap suggests that the bacteria from the OCSD outfall are not the same bacteria that contaminate the beaches. The bacteria causing the beach postings and closures at Huntington Beach are most likely coming from other sources, such as water from local storm drains, marshes, or some other as yet unidentified source.

Salinity data from the summer of 2001 clearly show two distinct bodies of relatively fresher (less saline) water-one offshore below the thermocline associated with the OCSD plume and one in shallower nearshore waters. This observation corresponds well to the spatial gap seen in the bacterial data. Al- though additional work needs to be done to identify the source of the nearshore body of fresher water, it may be coming from the San Gabriel and Los Angeles Rivers, to the north, which carry urban runoff into the ocean.

Beach closures from bacterial contamination continued at Huntington Beach in the summer of 2002. Even though the data show that the OCSD outfall plume is almost certainly not the source of that contamination, OCSD began chlorinating its wastewater discharge in the fall of 2002. Samples taken from the OCSD offshore outfall plume since then show low levels of bacteria, often below detection limits. However, periods of bacterial beach contamination at levels above AB411 standards have occurred at Huntington Beach after OCSD implemented chlorination, supporting the conclusion of the USGS-led study that the OCSD outfall plume is not the culprit in the beach contamination.

USGS and its cooperators are continuing to investigate how bacteria, other contaminants, and sediments are transported by coastal ocean processes not only off Huntington Beach but also in the larger region off southern California. Such research is only part of the USGS efforts to protect people's lives and property from geologic and environmental hazards in the coastal zones of the United States.

Jingping Xu, Marlene Noble, Leslie Rosenfeld, John Largier, Peter Hamilton, and Burt Jones

$$
\text { Edited by }
$$

James W. Hendley II and Peter H. Stauffer

Graphic design by

Susan Mayfield and Sara Boore

\section{COOPERATING ORGANIZATIONS}

MEC Analytical Systems, Inc.

Naval Postgraduate School

Orange County Sanitation District

Scientific Application International Corporation

Scripps Institute of Oceanography

University of Southern California

For more information contact:

U.S. Geological Survey

345 Middlefield Road, Mail Stop 999

Menlo Park, CA 94025

(650) 329-5042

http://walrus.wr.usgs.gov/

See also USGS Open-File Report 03-62 (http://

pubs.usgs.gov/of/2003/of03-62/).

This Fact Sheet and any updates to it are available online at: http://pubs.usgs.gov/fs/2003/fs024-03/ 